\title{
Risk factors for developing acute kidney injury in older people with diabetes and community-acquired pneumonia: a population-based UK cohort study
}

\author{
Anu Jain ${ }^{*}$, Helen I. McDonald, Dorothea Nitsch, Laurie Tomlinson and Sara L. Thomas
}

\begin{abstract}
Background: Acute kidney injury (AKI) is being increasingly recognised in ageing populations. There are a paucity of data about AKI risk factors among older individuals with diabetes and infections, who are at particularly high risk of AKI. The objective of this study was to evaluate the risk factors for developing acute kidney injury (AKI) amongst older patients with diabetes and community-acquired pneumonia (CAP) in England, and whether the impact of underlying kidney function varied with age.
\end{abstract}

Methods: This was a population-based retrospective cohort study over 7 years (01/04/2004-31/3/2011) using electronic health records from the Clinical Practice Research Datalink linked to Hospital Episode Statistics. The study population comprised individuals with diabetes aged $\geq 65$ years with CAP. Associations between demographic, lifestyle factors, co-morbidities and medications and development of AKI within 28 days of CAP were explored in a logistic regression model.

Results: Among 3471 patients with CAP and complete covariate data, 298 patients developed subsequent AKI. In multivariable analyses, factors found to be independently associated with AKI included: male sex (adjusted odds ratio, aOR: 1.56 95\% confidence interval (Cl): 1.20-2.04), hypertension (aOR1.36 95\% Cl 1.01-1.85), being prescribed either angiotensin-converting-enzyme inhibitors or angiotensin-II-receptor-blockers (aOR: 1.59 95\% Cl: 1.19-2.13), or insulin (aOR: 2.27 95\% Cl: 1.27-4.05), presence of proteinuria (aOR 1.27 95\% Cl 0.98-1.63), and low estimated glomerular filtration rate (eGFR). The odds of AKI were more graded amongst older participants aged $\geq 80$ years compared to those of younger age: for eGFR of $\leq 29 \mathrm{~mL} / \mathrm{min} / 1.73 \mathrm{~m}^{2}$ (vs $60 \mathrm{ml} / \mathrm{min} / 1.73 \mathrm{~m}^{2}$ ) aOR: $5.5195 \% \mathrm{Cl} 3.28-9.27$ and for eGFR $30-59 \mathrm{~mL} / \mathrm{min} / 1.73 \mathrm{~m}^{2} 1.9695 \% \mathrm{Cl} 1.30-2.96$, whilst any eGFR $<60 \mathrm{ml} / \mathrm{min} / 1.73 \mathrm{~m}^{2}$ was associated with approximately 3 -fold increase in the odds of AKI amongst younger individuals ( $p$-value for interaction $=0.007$ ).

Conclusions: The identified risk factors should help primary care and hospital providers identify high risk patients in need of urgent management including more intensive monitoring, and prevention of AKI following pneumonia.

Keywords: Acute kidney injury, Diabetes, Older, Community-acquired pneumonia, UK

\footnotetext{
* Correspondence: Anu.jain@lshtm.ac.uk

Faculty of Epidemiology and Population Health, London School of Hygiene and Tropical Medicine, London WC1E7HT, UK
}

(c) The Author(s). 2017 Open Access This article is distributed under the terms of the Creative Commons Attribution 4.0 International License (http://creativecommons.org/licenses/by/4.0/, which permits unrestricted use, distribution, and reproduction in any medium, provided you give appropriate credit to the original author(s) and the source, provide a link to the Creative Commons license, and indicate if changes were made. The Creative Commons Public Domain Dedication waiver (http://creativecommons.org/publicdomain/zero/1.0/) applies to the data made available in this article, unless otherwise stated. 


\section{Background}

Acute kidney injury (AKI, a term introduced for acute renal failure in 2004) is a clinical syndrome of sudden renal impairment, and is associated with adverse prognosis [1, 2]. The global incidence of AKI in hospitalised adults reported in a 2013 metaanalysis was $\sim 22 \%$ with a mortality rate of $\sim 24 \%$ [3]. Other adverse outcomes associated with AKI include end-stage renal disease, chronic kidney disease (CKD) and a higher risk of cardio-vascular events [4-6].

Risk factors for AKI include severe infections, diabetes, older age and CKD [7, 8]. Older individuals with diabetes are a group at particular risk of AKI owing to multiple risk factors such as age, presence of other co-morbidities including CKD, and predisposition to serious infections [9]. A common infection in this population group is community-acquired pneumonia (CAP) [10-14], and a recent review [15] reported rate ratios ranging from 1.5 to 3.1 for CAP amongst people with diabetes compared to those without diabetes. AKI triggered by infection, including both severe and non-severe CAP, carries grave prognosis with higher mortality and morbidity requiring longer hospitalisation [16-19]. The consequences of AKI in older people with diabetes who develop pneumonia could be therefore severe, with incomplete renal recovery $[5,6]$. The reasons for these adverse events following AKI amongst older individuals with diabetes following pneumonia are unclear. A study did not find differences in immune marker levels amongst individuals with and without diabetes following hospitalisation for CAP [20]. However, in this study mortality was high after CAP especially in those with diabetes, and AKI was a common problem [20]. The specific risk factors for AKI in this high risk group have not been examined in previous studies [19, 21-23].

The primary objective of this study was to determine risk factors for developing AKI within 28 days of incident CAP in patients with diabetes aged $\geq 65$ years in England. The secondary objective was to assess whether any increased risk of AKI associated with reduced estimated glomerular filtration rate (eGFR) or proteinuria varied with age. The hypothesis was that older participants with reduced eGFR may be more predisposed to AKI compared to younger individuals because of decreasing renal functional reserve [24].

\section{Methods}

The data source for this study was the Clinical Practice Research Datalink (CPRD) containing anonymised patient records from UK general practices covering $\sim 7 \%$ of the population and including cumulatively 79 million person-years of follow-up $[25,26]$. This longitudinal and qualityassured database provides clinical, treatment, laboratory, demographic and lifestyle information for patients seen in primary care [26]. In England, $75 \%$ of CPRD general practices have consented to linkages with hospitalisation data (Hospital Episode Statistics, HES) and small-area level deprivation data (Index of Multiple Deprivation, IMD) [26]. In HES, the period between admission and discharge is known as a 'spell' which comprises of one or several episodes that are the periods of continuous care from a single consultant. The record for each spell is composed of a list of diagnoses occurring during each episode of the patient's admission [27].

This study is a subset of a large retrospective cohort of older patients with diabetes, used to investigate risks associated with CKD and infections up to March 2011. Details of the overall study population and the algorithms used to diagnose CAP and other infections are published elsewhere $[28,29]$. For this study, the study population comprised individuals aged $\geq 65$ years with diabetes mellitus in England whose general practices consented to dataset linkages, and who had a first diagnosis of CAP between April 2004 and March 2011. The start date was chosen to ensure that the study followed the introduction of the Quality and Outcomes Framework in 2004 which standardised management of chronic conditions in primary care [30], and the introduction of consensus criteria for AKI (also in 2004) [31]. Individuals who had a first CAP diagnosis less than a year after they registered with the practice were excluded, as these could be historical episodes of CAP that were recorded retrospectively in the first few months after registration [32].

\section{Outcome and exposure data}

The outcome of interest was AKI diagnosed in hospital, with the hospital episode start date within 28 days of the CAP diagnosis. This included patients who were diagnosed and treated with CAP in primary care; follow-up was not limited to hospitalisation for CAP but included any admission for AKI in the 28 days following CAP diagnosis. The primary definition of AKI was a record in the HES data coded with the specific International Classification of Diseases-10 (ICD-10) code N17 (acute renal failure). Patients with either ICD-10 codes N17 or N19 (unspecified kidney failure) were 
used in sensitivity analyses to capture additional patients with AKI who might have been coded with the less specific ICD-10 code.

Potential risk factors for AKI identified in previous studies were examined [19, 21, 33-37]. These included older age, gender, body mass index (BMI), deprivation (IMD), smoking status and alcohol intake; nine co-morbidities: CKD, hypertension, congestive cardiac failure, ischemic heart disease, cerebrovascular disease, dementia, chronic lung disease, malignancies, connective tissue disease and three medications: the prescription of angiotensin converting enzyme inhibitors (ACEI) and/or angiotensin II receptor blockers (ARBs) prescribed within 6 months of CAP onset, and lifetime history of anti-diabetes prescriptions (oral hypoglycaemic drugs and/or insulin) prior to infection. Socio-economic status was ascertained using 2007 Office for National Statistics' IMD, a composite area-level marker of deprivation categorised in quintiles (1, least deprived; to 5, most deprived) [38]. Records with missing individual level IMD were substituted with values for the relevant general practice. All other risk factors were defined using primary care records in CPRD. The most recent glycated haemoglobin level that was recorded at least 28 days prior to infection onset (to describe baseline glycaemic control independent of incipient CAP) was used. BMI was estimated using the weight recorded closest to the CAP onset date and categorised into underweight $\left(<18.5 \mathrm{~kg} / \mathrm{m}^{2}\right)$, healthy weight $\left(18.5-24.9 \mathrm{~kg} / \mathrm{m}^{2}\right)$, overweight $\left(25-29.9 \mathrm{~kg} / \mathrm{m}^{2}\right)$ and obese $\left(\geq 30 \mathrm{~kg} / \mathrm{m}^{2}\right)$. Similarly, smoking status (non-, current or ex-smoker) and alcohol intake (non-, ex-, current up to 6 units/day and heavy $>6$ units/day) were ascertained using the last record prior to CAP onset and if this was unavailable then the earliest record after the infection onset were used. Diagnostic Read codes at any time prior to CAP onset date were used to identify the nine co-morbidities of interest, and prescription records at any time prior to CAP onset for medication history. Underlying renal function was ascertained from primary care records using either estimated glomerular filtration rate (eGFR, from laboratory reports) or presence of proteinuria without urinary tract infection (from laboratory reports or Read codes for proteinuria or proteinuric disease recorded by GPs), as detailed in our previous study [39]. In brief, eGFR was based on the latest serum creatinine result recorded prior to CAP onset (excluding results recorded within 28 days of CAP onset as these may reflect the effect of acute infection rather than pre-existing underlying renal function) and was estimated using the Chronic Kidney Disease Epidemiology Collaboration equation adjusted for ethnicity [40]. It was classified under three categories: $\geq 60,30-59$ and $\leq 29 \mathrm{~mL} / \mathrm{min} / 1.73 \mathrm{~m}^{2}$ to maintain adequate numbers in each group. Proteinuria was identified by a positive urine protein test (without a concurrent urinary tract infection), or by any Read code recording proteinuric disease as previously described [39].

\section{Data analysis}

Individuals were followed up from the CAP diagnosis date (the index date) until the earliest of: 28 days after the CAP diagnosis, AKI diagnosis, patient's death or transfer out of the practice, the last date at which the practice contributed data, the last HES linkage date, initiation of renal replacement therapy (recorded in either CPRD or HES) or 31/03/11.

Multivariable logistic regression was used to examine the association of explanatory variables with presence or absence of an AKI-code in the 28 days after CAP, using odds ratios (OR) and 95\% confidence interval (CI). Individuals with complete covariate data were included in analyses.

Age, gender and study-period were considered a priori confounders as well as potential explanatory variables in their own right. The study period split into two categories, April 2004-September 2007 and October 2007-March 2011, to assess the impact of the Acute Kidney Injury Network (AKIN) criteria introduced in 2007 [41]. The ORs for each explanatory variable were first examined in a minimally adjusted model, adjusted for the three a priori confounders. Hypothesis testing was conducted using likelihood ratio test. Ordered categorical variables such as eGFR, BMI, smoking-status, alcohol-intake and the study-period were also examined for linear trend.

A conceptual framework describing the hypothesised hierarchy of risk factors for AKI was then developed (Fig. 1) to inform the building of a multivariable model to determine risk factors for AKI [19, 21, 33, 34, 36, 37]. Deprivation (IMD) was considered a distal determinant [42], that mediates its effect first via lifestyle factors (BMI, smoking and alcohol) and then via more proximate determinants [42]: hypertension and other co-morbidities, which themselves could act partly via medications (Fig. 1). These variables were added sequentially to the minimally adjusted model in the order of their hypothesised position in the causal pathway to AKI.

Being cautious about data sparsity and collinearity, the number of variables included in the final model was restricted to ensure at least ten outcomes per parameter estimate [43]. If data sparsity was encountered the decision for inclusion in the final model was based on the magnitude of the effect estimates in the minimally 


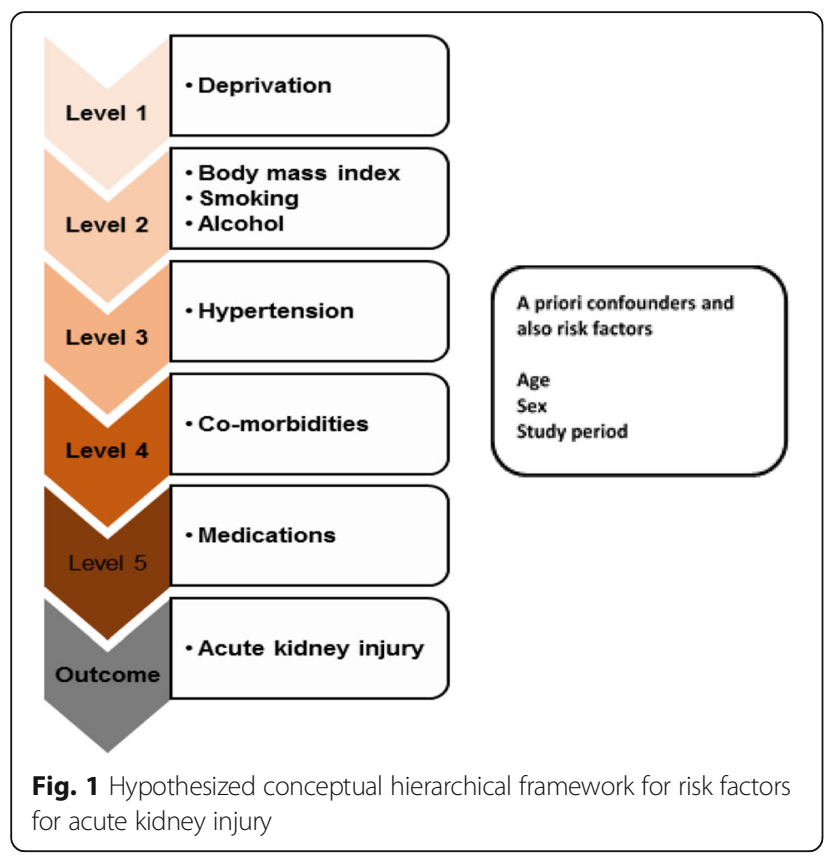

adjusted model and $P$-values of $<0.2$. Collinearity was assessed by comparing the log standard errors of the coefficients in the multivariable models.

An interaction of a priori interest, namely between age and renal functional reserve was examined by fitting the final multivariable model first with interaction terms between age and eGFR and then between age and proteinuria. Age was re-categorised as a binary variable to examine effect modification (65-79 years and $\geq 80$ years) and models with and without interaction terms were compared using the likelihood ratio tests.

Three sensitivity analyses were conducted: (1) an analysis including individuals who were excluded from the primary analysis because of missing data, dropping selected variables with missing data; (2) repeating analyses after categorising AKI using both ICD-10 N19 and N17 codes, to capture non-specific coding for AKI; and (3) repeating the final multivariable analyses for only those individuals who were hospitalised within 28 days (for any reason) of CAP diagnosis to minimise ascertainment bias of AKI.

\section{Results}

The study population included a total of 4115 patients with CAP, of whom $346(8.4 \%)$ had AKI. Data were missing for five variables (Table 1): BMI (7.6\%), alcohol-intake (7.5\%), HbA1C (4.7\%), eGFR (1.2\%) and smoking-status (0.5\%); data on individual IMD were available for $91.1 \%$ of individuals, with IMD for the general practice used for the remaining $8.9 \%$.

The complete case analyses included 3471 patients, with 298 (8.6\%) cases of AKI. Most (3047/ $3471(87.8 \%))$ of the patients with CAP were hospitalised. A comparison of patients included and excluded from analysis is shown in Table 1 . Briefly, those included in analysis were more likely to be males, younger, ex-smokers, current alcoholconsumers and with raised BMI. They were also more likely to have records of proteinuria, hypertension and ischaemic heart disease and to have been prescribed ACEI or ARBs or antidiabetic medications, but were less likely to have dementia.

\section{Minimally adjusted analysis}

In the analysis adjusted for age, gender and study period (Table 2 column 2), there was little evidence of an association between most demographic and lifestyle factors (age, deprivation, smoking and alcohol intake) and AKI, except for increased odds of AKI amongst males and the most obese individuals (BMI $\geq 30 \mathrm{~kg} / \mathrm{m}^{2}$ ). More AKI diagnoses were observed in the second half of study period. Amongst the nine co-morbidities examined as risk factors, the odds for AKI in patients with hypertension was 1.6 times higher compared to those without hypertension. There was also very strong evidence for an association with underlying renal function: there was a linear trend in increasing odds of AKI with decreasing eGFR, with those with eGFR $\leq 29$ at more than five times the odds of AKI, and those with proteinuria at 1.7 times the odds of AKI. In contrast, there was some evidence for reduced odds for AKI among those with connective tissue disease and cancer. For medication, higher odds of AKI were observed amongst patients taking either ACEI/ARB, and among those prescribed insulin. Due to concerns about data-sparsity, IMD (the least strongly associated variable in this analysis) was dropped from further models.

\section{Multivariable analysis}

The multivariable models were built sequentially as described in the Methods. After adjusting for lifestyle and socio-demographic factors (Table 4 in Appendix) and then for hypertension, and then other co-morbidities (Model 4: Table 2, column 4), the increased odds associated with hypertension persisted and the linear increased odds of AKI with 
Table 1 Baseline characteristics of patients included and excluded from analyses (2004-2011)

\begin{tabular}{|c|c|c|c|c|c|}
\hline \multirow[t]{2}{*}{ Characteristics } & & \multicolumn{2}{|c|}{ Patients included in analysis } & \multicolumn{2}{|c|}{ Patients excluded from analysis } \\
\hline & & Total $N=3471$ & With $A K I=298$ & Total $N=644$ & With $\mathrm{AKI}=48$ \\
\hline Females & & $1558(44.9)$ & $113(37.9)$ & $384(59.6)$ & $25(52.1)$ \\
\hline \multirow[t]{5}{*}{ Age (years) } & $65-69$ & $414(11.9)$ & $31(10.4)$ & $53(8.2)$ & $3(6.3)$ \\
\hline & $70-74$ & $587(16.9)$ & $39(13.1)$ & $66(10.3)$ & $4(8.3)$ \\
\hline & $75-79$ & $725(20.9)$ & $60(20.1)$ & $100(15.5)$ & $6(12.5)$ \\
\hline & $80-84$ & $810(23.3)$ & $72(24.2)$ & $141(21.9)$ & $14(29.2)$ \\
\hline & $\geq 85$ & $935(26.9)$ & $96(32.2)$ & $284(44.1)$ & $21(43.8)$ \\
\hline \multirow[t]{5}{*}{$\mathrm{IMD}^{\mathrm{a}}$} & 1 (least deprived) & $575(16.6)$ & $48(16.1)$ & $102(15.8)$ & $6(12.5)$ \\
\hline & 2 & $808(23.3)$ & $72(24.2)$ & $166(25.8)$ & $17(35.4)$ \\
\hline & 3 & $742(21.4)$ & $63(21.1)$ & $141(21.9)$ & $11(22.9)$ \\
\hline & 4 & $756(21.8)$ & $67(22.5)$ & $124(19.3)$ & 7 (14.6) \\
\hline & 5 (most deprived) & $590(17.0)$ & $48(16.1)$ & $111(17.2)$ & $7(14.6)$ \\
\hline \multirow[t]{4}{*}{ Smoking status } & Non-smoker & $851(24.5)$ & $64(21.5)$ & $275(42.7)$ & $20(41.7)$ \\
\hline & Current smoker & $634(18.3)$ & $53(17.8)$ & $94(14.6)$ & $6(12.5)$ \\
\hline & Ex-smoker & 1986 (57.2) & $181(60.7)$ & $253(39.3)$ & $20(41.7)$ \\
\hline & Missing & $0(0.0)$ & $0(0.0)$ & $22(3.4)$ & $2(4.2)$ \\
\hline \multirow[t]{5}{*}{ Alcohol intake $u /$ day } & Non-drinker & $517(14.9)$ & $45(15.1)$ & $83(12.9)$ & $10(20.8)$ \\
\hline & Ex-drinker & $530(15.3)$ & $53(17.8)$ & $38(5.9)$ & $4(8.3)$ \\
\hline & Current $\leq 6$ units/day & $2281(65.7)$ & $192(64.4)$ & 199 (30.9) & $7(14.6)$ \\
\hline & Heavy $>6$ units/day & $143(4.1)$ & $8(2.7)$ & $17(2.6)$ & $4(8.3)$ \\
\hline & Missing & $0(0.0)$ & $0(0.0)$ & $307(47.7)$ & $23(47.9)$ \\
\hline \multirow[t]{5}{*}{ BMI categories $\left(\mathrm{kg} / \mathrm{m}^{2}\right)$} & $15-18.4$ & $126(3.6)$ & $9(3.0)$ & $23(3.6)$ & $1(2.1)$ \\
\hline & $18.5-24.9$ & 1177 (33.9) & 97 (32.6) & $110(17.1)$ & $8(16.7)$ \\
\hline & $25-29.9$ & 1173 (33.8) & $93(31.2)$ & $123(19.1)$ & $13(27.1)$ \\
\hline & $\geq 30$ & $995(28.7)$ & $99(33.2)$ & $77(12.0)$ & $6(12.5)$ \\
\hline & Missing & $0(0.0)$ & $0(0.0)$ & $311(48.3)$ & $20(41.7)$ \\
\hline \multirow[t]{4}{*}{ eGFR $\left(\mathrm{mL} / \mathrm{min} / 1.73 \mathrm{~m}^{2}\right)$} & $\leq 29$ & $280(8.1)$ & $54(18.1)$ & $46(7.1)$ & $8(16.7)$ \\
\hline & $30-59$ & $1487(42.8)$ & $165(55.4)$ & $262(40.7)$ & 19 (39.6) \\
\hline & $\geq 60$ & $1704(49.1)$ & 79 (26.5) & $288(44.7)$ & 19 (39.6) \\
\hline & Missing & $0(0.0)$ & $0(0.0)$ & $48(7.5)$ & $2(4.2)$ \\
\hline \multicolumn{2}{|l|}{ Proteinuria } & $1326(38.2)$ & $152(51.0)$ & 109 (16.9) & $11(22.9)$ \\
\hline \multicolumn{2}{|l|}{ Hypertension } & $2450(70.6)$ & $236(79.2)$ & $368(57.1)$ & $31(64.6)$ \\
\hline \multicolumn{2}{|l|}{ Congestive cardiac failure } & $743(21.4)$ & $74(24.8)$ & 119 (18.5) & 7 (14.6) \\
\hline \multicolumn{2}{|l|}{ Ischaemic heart disease } & $1326(38.2)$ & $108(36.2)$ & $167(25.9)$ & $11(22.9)$ \\
\hline \multicolumn{2}{|l|}{ Cerebrovascular diseases } & $919(26.5)$ & $80(26.9)$ & $189(29.4)$ & $18(37.5)$ \\
\hline \multicolumn{2}{|l|}{ Dementia } & $239(6.9)$ & $23(7.7)$ & 107 (16.6) & $7(14.6)$ \\
\hline \multicolumn{2}{|l|}{ Chronic lung disease } & $895(25.8)$ & $67(22.5)$ & $143(22.2)$ & $13(27.1)$ \\
\hline \multicolumn{2}{|l|}{ Cancer } & $638(18.4)$ & $46(15.4)$ & $112(17.4)$ & $6(12.5)$ \\
\hline \multicolumn{2}{|l|}{ Connective tissue diseases } & $329(9.5)$ & $19(6.4)$ & $58(9.0)$ & $4(8.3)$ \\
\hline \multicolumn{2}{|l|}{ ACEls } & $1603(46.2)$ & $164(55.0)$ & $212(32.9)$ & $25(52.1)$ \\
\hline \multicolumn{2}{|l|}{ ARBs } & $579(16.7)$ & $70(23.5)$ & $45(7.0)$ & $3(6.2)$ \\
\hline \multicolumn{2}{|l|}{ Either ACEIs/ ARBs } & $2105(60.7)$ & $220(73.8)$ & $253(39.3)$ & $27(56.2)$ \\
\hline
\end{tabular}


Table 1 Baseline characteristics of patients included and excluded from analyses (2004-2011) (Continued)

\begin{tabular}{|c|c|c|c|c|c|}
\hline \multirow[t]{4}{*}{$\mathrm{HBA} 1 \mathrm{C}$} & Good $<7 \%$ & $1887(54.4)$ & $163(54.7)$ & $278(43.2)$ & $20(41.7)$ \\
\hline & Borderline $7-10 \%$ & $1427(41.1)$ & $122(40.9)$ & $146(22.7)$ & $12(25.0)$ \\
\hline & High >10\% & $157(4.5)$ & $13(4.4)$ & $25(3.9)$ & $4(8.3)$ \\
\hline & Missing & $0(0.0)$ & $0(0.0)$ & $195(30.3)$ & $12(25.0)$ \\
\hline \multirow[t]{4}{*}{ Medication-diabetes } & None & $859(24.8)$ & $64(21.5)$ & $270(41.9)$ & $18(37.5)$ \\
\hline & Oral & $1802(51.9)$ & $144(48.3)$ & $264(41.0)$ & $20(41.7)$ \\
\hline & Insulin & $142(4.1)$ & $22(7.4)$ & $43(6.7)$ & $4(8.3)$ \\
\hline & Both & $668(19.3)$ & $68(22.8)$ & $67(10.4)$ & $6(12.5)$ \\
\hline \multirow[t]{2}{*}{ Study period } & April 2004- Sep.2007 & $1325(38.2)$ & $57(19.1)$ & $331(51.4)$ & $12(25.0)$ \\
\hline & Oct.2007-March 2011 & $2146(61.8)$ & $241(80.9)$ & $313(48.6)$ & $36(75.0)$ \\
\hline
\end{tabular}

(\%) column percentages IMD index of multiple deprivation ${ }^{\mathrm{a}} 8.9 \%$ records with missing individual index of multiple deprivation were substituted by values for general practice u units; BMI body mass index, eGFR estimated glomerular filtration rate, $A C E / s$ angiotensin converting enzyme inhibitors, $A R B s$ angiotensin II receptor blockers, HBA1C glycated-haemoglobin levels Sep. September Oct. October

reducing eGFR were still observed. However, the previously observed strong evidence of higher odds of AKI with proteinuria was reduced $(P=0.07)$ and the association of high BMI with AKI seen in the previous model disappeared.

In the final multivariable analysis (Model 5: Table 2 column 6), ACEI/ARB users had $60 \%$ increased odds of AKI after adjusting for the other co-morbidities and lifestyle factors. The increased risk of AKI with insulin use remained. The previously observed association of AKI with BMI, hypertension and proteinuria was attenuated after adjusting for these additional mediating variables. There was evidence of lower odds of AKI amongst patients with ischemic heart disease.

\section{Effect modification by age}

Table 3 shows the age-specific ORs for the association of AKI with eGFR and proteinuria as markers of CKD. There was strong evidence $\left(\mathrm{P}_{\text {interaction }}=0.007\right)$ of an interaction between age and eGFR after adjusting for other risk factors for AKI, with a more pronounced effect of eGFR $<30 \mathrm{~mL} / \mathrm{min} / 1.73 \mathrm{~m}^{2}$ on AKI amongst those aged $\geq 80$ years (adjusted-OR 5.51 95\% CI 3.28-9.27) compared to the younger group (adjusted-OR 2.90 $95 \%$ CI 1.46-5.77). In the older individuals (aged $\geq 80$ years) the graded increase in odds of AKI with decreasing eGFR remained but this graded association was not evident in the younger agegroup for whom any eGFR $<60 \mathrm{ml} / \mathrm{min} / 1.73 \mathrm{~m}^{2}$ was associated with an approximately three fold increase in AKI risk (Table 3).

In contrast, there was little evidence $\left(P_{\text {interaction }}=0.34\right)$ that the effect of proteinuria on AKI varied by age.
Sensitivity analyses (Tables 5, 6 and 7 in Appendix)

After excluding the four variables with missing data that had less strong evidence of an association with AKI (smoking status, alcohol intake, BMI and $\mathrm{HbA1C}$ ) there were 4067 individuals included in the analysis. The results from this model were similar to those of the main model (Table 5 in Appendix).

After widening the definition of AKI to include the non-specific N19 code, the number of patients who developed AKI increased from 298 (coded only as ICD10 N17) to 373 (coded either ICD-10 N17 or N19). The lower odds associated with connective tissue diseases was no longer apparent in this model, but no other appreciable changes were evident (Table 6 in Appendix).

Amongst those hospitalised the overall risk of developing AKI was 9.8\% $(N=298)$. Results after restricting analyses to those who were hospitalised were very similar to those in the entire study population (Table 7 in Appendix).

\section{Discussion}

Amongst older individuals with diabetes and CAP the overall risk for AKI within 28 days of incident CAP diagnosis was $8.4 \%$ for the entire cohort and $9.8 \%$ amongst those who were hospitalised. The risk factors independently associated with AKI were male sex, reduced eGFR, absence of ischemic heart disease, use of ACEIs/ARBs and insulin. The association of hypertension and proteinuria with AKI attenuated after adjusting for ACEIs/ARBs use. The association of reducing eGFR with AKI was found to be more prominent amongst individuals aged $\geq 80$ years, whilst any eGFR $<60 \mathrm{ml} / \mathrm{min} / 1.73 \mathrm{~m}^{2}$ was associated with AKI risk amongst younger study participants. 
Table 2 Multivariable analyses of the association of risk factors and acute kidney injury $(N=3471)$

\begin{tabular}{|c|c|c|c|c|c|c|c|}
\hline \multicolumn{2}{|l|}{ Characteristics } & $\begin{array}{l}\text { Model } 1 \text { adjusted for } \\
\text { age, sex and period } \\
\text { OR }(95 \% \mathrm{Cl})\end{array}$ & $\begin{array}{l}P \text { value }^{a} \\
\left(\mathrm{P}_{\mathrm{T}}\right)\end{array}$ & $\begin{array}{l}\text { Model } 4^{c} \text { adjusted for all } \\
\text { variables in table except } \\
\text { IMD, medications and HBA1C } \\
\text { OR }(95 \% \mathrm{Cl})\end{array}$ & $\begin{array}{l}P \text { value } \\
\left(P_{T}\right)\end{array}$ & $\begin{array}{l}\text { Model } 5 \text { additionally } \\
\text { adjusted for medications } \\
\text { \& HBA1C } \\
\text { OR }(95 \% \mathrm{Cl})\end{array}$ & $\begin{array}{l}P \text { value } \\
\left(P_{T}\right)\end{array}$ \\
\hline \multicolumn{2}{|l|}{ Females } & $0.71(0.56-0.91)$ & 0.007 & $0.63(0.48-0.82)$ & 0.0005 & $0.64(0.49-0.83)$ & 0.0008 \\
\hline \multirow[t]{5}{*}{ Age years } & $65-69$ & $0.67(0.44-1.03)$ & 0.11 & $0.92(0.57-1.48)$ & 0.74 & $0.83(0.52-1.35)$ & 0.55 \\
\hline & $70-74$ & $0.62(0.42-0.92)$ & & $0.76(0.50-1.17)$ & & $0.70(0.46-1.09)$ & \\
\hline & $75-79$ & $0.75(0.53-1.06)$ & & $0.83(0.57-1.20)$ & & $0.78(0.54-1.13)$ & \\
\hline & $80-84$ & $0.84(0.61-1.17)$ & & $0.88(0.63-1.24)$ & & $0.84(0.59-1.18)$ & \\
\hline & $\geq 85$ & 1 & & 1 & & 1 & \\
\hline \multirow[t]{5}{*}{$\mathrm{IMD}^{\mathrm{b}}$} & 1 (least deprived) & 1 & & Not in model & & Not in model & \\
\hline & 2 & $1.09(0.74-1.60)$ & 0.96 & & & & \\
\hline & 3 & $1.07(0.72-1.59)$ & & & & & \\
\hline & 4 & $1.16(0.78-1.72)$ & & & & & \\
\hline & $\begin{array}{l}5 \text { (most } \\
\text { deprived) }\end{array}$ & $1.06(0.69-1.61)$ & & & & & \\
\hline \multirow[t]{3}{*}{ Smoking status } & Non-smoker & 1 & & 1 & & 1 & \\
\hline & Current smoker & $1.12(0.76-1.67)$ & 0.74 & $1.32(0.87-2.00)$ & 0.36 & $1.39(0.92-2.11)$ & 0.25 \\
\hline & Ex-smoker & $1.13(0.83-1.53)$ & & $1.22(0.88-1.68)$ & & $1.26(0.91-1.74)$ & \\
\hline \multirow{4}{*}{$\begin{array}{l}\text { Alcohol intake } \\
\text { (u/day) }\end{array}$} & Non-drinker & 1 & & 1 & & 1 & \\
\hline & Ex-drinker & $0.98(0.64-1.50)$ & 0.27 & $1.00(0.65-1.55)$ & 0.40 & $1.00(0.64-1.55)$ & 0.43 \\
\hline & $\begin{array}{l}\text { Current } \\
\leq 6 \text { units/day }\end{array}$ & $0.83(0.59-1.18)$ & & $0.86(0.60-1.23)$ & & $0.88(0.61-1.26)$ & \\
\hline & $\begin{array}{l}\text { Heavy } \\
>6 \text { units/day }\end{array}$ & $0.52(0.24-1.15)$ & & $0.56(0.25-1.26)$ & & $0.55(0.24-1.26)$ & \\
\hline \multirow[t]{4}{*}{ BMI $\left(\mathrm{kg} / \mathrm{m}^{2}\right)$} & $15-18.4$ & $0.80(0.39-1.64)$ & 0.05 & $0.90(0.43-1.88)$ & 0.50 & $0.95(0.45-2.00)$ & 0.53 \\
\hline & $18.5-24.9$ & 1 & & 1 & & 1 & \\
\hline & $25-29.9$ & $1.00(0.74-1.35)$ & & $0.92(0.67-1.25)$ & & $0.90(0.65-1.23)$ & \\
\hline & $\geq 30$ & $1.44(1.05-1.97)$ & & $1.17(0.85-1.62)$ & & $1.14(0.82-1.58)$ & \\
\hline \multirow{3}{*}{$\begin{array}{l}\text { eGFR } \\
\left(\mathrm{mL} / \mathrm{min} / 1.73 \mathrm{~m}^{2}\right)\end{array}$} & $\leq 29$ & $5.53(3.75-8.15)$ & $<0.0001$ & $4.80(3.18-7.23)$ & $<0.0001$ & $4.62(3.06-6.99)$ & $<0.0001$ \\
\hline & $30-59$ & $2.74(2.06-3.66)$ & $(<0.0001)$ & $2.58(1.92-3.47)$ & $(<0.0001)$ & $2.48(1.84-3.33)$ & $(<0.0001)$ \\
\hline & $\geq 60$ & 1 & & 1 & & 1 & \\
\hline \multicolumn{2}{|l|}{ Proteinuria } & $1.66(1.30-2.11)$ & $<0.0001$ & $1.27(0.98-1.63)$ & 0.07 & $1.23(0.95-1.59)$ & 0.12 \\
\hline \multicolumn{2}{|l|}{ Hypertension } & $1.63(1.21-2.19)$ & 0.0007 & $1.36(1.01-1.85)$ & 0.04 & $1.27(0.93-1.73)$ & 0.13 \\
\hline \multicolumn{2}{|c|}{ Congestive cardiac failure } & $1.24(0.94-1.64)$ & 0.13 & $1.07(0.79-1.45)$ & 0.65 & $1.03(0.76-1.39)$ & 0.86 \\
\hline \multicolumn{2}{|c|}{ Ischaemic heart disease } & $0.90(0.70-1.15)$ & 0.4 & $0.79(0.61-1.03)$ & 0.08 & $0.76(0.58-1.00)$ & 0.04 \\
\hline \multicolumn{2}{|c|}{ Cerebrovascular diseases } & $1.00(0.76-1.31)$ & 0.99 & $0.90(0.68-1.19)$ & 0.44 & $0.90(0.68-1.20)$ & 0.47 \\
\hline \multicolumn{2}{|l|}{ Dementia } & $1.05(0.66-1.65)$ & 0.85 & $1.12(0.70-1.80)$ & 0.64 & $1.17(0.73-1.88)$ & 0.53 \\
\hline \multicolumn{2}{|c|}{ Chronic lung disease } & $0.79(0.59-1.06)$ & 0.11 & $0.79(0.59-1.07)$ & 0.12 & $0.79(0.58-1.07)$ & 0.12 \\
\hline \multicolumn{2}{|l|}{ Cancer } & $0.72(0.52-1.01)$ & 0.05 & $0.73(0.52-1.03)$ & 0.07 & $0.76(0.54-1.07)$ & 0.11 \\
\hline \multicolumn{2}{|c|}{ Connective tissue diseases } & $0.63(0.39-1.01)$ & 0.04 & $0.64(0.39-1.05)$ & 0.06 & $0.66(0.40-1.08)$ & 0.08 \\
\hline \multicolumn{2}{|l|}{ Either ACEIs/ ARBs } & $1.96(1.49-2.58)$ & $<0.0001$ & Not in model & & $1.59(1.19-2.13)$ & 0.002 \\
\hline \multirow[t]{3}{*}{ HBA1C levels } & Good $<7 \%$ & 1 & & Not in model & & 1 & \\
\hline & Borderline 7-10\% & $1.01(0.79-1.30)$ & 0.98 & & & $0.82(0.62-1.09)$ & 0.38 \\
\hline & High >7\% & $0.95(0.52-1.73)$ & & & & $0.82(0.43-1.54)$ & \\
\hline
\end{tabular}


Table 2 Multivariable analyses of the association of risk factors and acute kidney injury $(N=3471)$ (Continued)

\begin{tabular}{|c|c|c|c|c|c|c|c|}
\hline \multirow{4}{*}{$\begin{array}{l}\text { Medication } \\
\text { diabetes }\end{array}$} & None & 1 & & Not in model & & 1 & \\
\hline & Oral & $1.10(0.81-1.50)$ & 0.005 & & & $1.05(0.75-1.46)$ & 0.05 \\
\hline & Insulin & $2.49(1.46-4.23)$ & & & & $2.27(1.27-4.05)$ & \\
\hline & Both & $1.43(0.99-2.07)$ & & & & $1.11(0.72-1.71)$ & \\
\hline \multirow[t]{2}{*}{ Period } & $\begin{array}{l}\text { April 2004- } \\
\text { Sep. } 2007\end{array}$ & 1 & $<0.0001$ & 1 & $<0.0001$ & 1 & $<0.0001$ \\
\hline & $\begin{array}{l}\text { Oct. 2007- } \\
\text { March } 2011\end{array}$ & $2.79(2.07-3.76)$ & $(<0.0001)$ & $2.91(2.14-3.94)$ & $(<0.0001)$ & $2.90(2.14-3.95)$ & $(<0.0001)$ \\
\hline
\end{tabular}

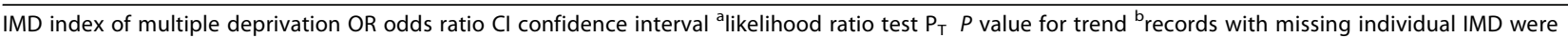
substituted by values for general practice ${ }^{C}$ Model 2 and 3 are presented in Table 4 in Appendix u units; BMI body mass index, eGFR estimated glomerular filtration rate, $A C E I$ angiotensin converting enzyme inhibitors, $A R B s$ angiotensin II receptor blockers Sep. September Oct. October

The risk of $9.8 \%$ found in this cohort is lower than that reported by a Scottish study [23] that found AKI incidence of $18 \%$ amongst CAP patients at time of hospital admission. Another study [19] reported AKI incidence of $34 \%$ any time during hospitalisation in CAP patients aged $\geq 18$ years. In both these studies the diagnosis of CAP was confirmed in the hospital and were not confined to individuals with diabetes $[19,23]$. In the present study CAP diagnosis in general practice (which is mainly a clinical diagnosis) could have led to a higher study denominator and perhaps an underestimation of the risk of AKI.
A temporal change in increased AKI diagnosis during the period of 2007-2011, as observed in previous studies using CPRD and HES [44, 45] was also evident in this study, reflecting better ascertainment of outcome in the latter period. In the earlier period of the study, coded AKI events are likely to have been for the more serious forms of AKI [46]. This is not necessarily a draw-back as the analyses identifies those at highest risk of more severe AKI. The validation of recording of AKI (during 2005 and 2010) in UK hospital data has been previously described [44] with a high positive predictive value (95\%) for AKI codes in these data.

Table 3 Association of pre-existing eGFR and proteinuria with acute kidney injury stratified by age $(N=3471)$

\begin{tabular}{|c|c|c|c|c|c|}
\hline & $\begin{array}{l}\text { eGFR } \\
\left(\mathrm{mL} / \mathrm{min} / 1.73 \mathrm{~m}^{2}\right)\end{array}$ & Total & $\begin{array}{l}\text { With AKI } \\
\mathrm{N}(\%)\end{array}$ & $\begin{array}{l}\text { Stratum-specific adjusted } \\
\text { OR for acute kidney injury }(95 \% \mathrm{Cl})\end{array}$ & $\begin{array}{l}P \text {-value for } \\
\text { interaction }^{\mathrm{b}}\end{array}$ \\
\hline \multirow[t]{4}{*}{ Age 65-79 } & $\leq 29$ & 102 & $13(12.8)$ & $2.90(1.46-5.77)$ & \multirow[t]{4}{*}{0.007} \\
\hline & $30-59$ & 586 & 74 (12.6) & $3.29(2.20-4.94)$ & \\
\hline & $\geq 60$ & 1038 & $43(4.1)$ & 1 & \\
\hline & Total & 1726 & $130(7.5)$ & & \\
\hline \multirow[t]{5}{*}{ Age 80 or above } & $\leq 29$ & 178 & $41(23)$ & $5.51(3.28-9.27)$ & \\
\hline & $30-59$ & 901 & $91(10.1)$ & $1.96(1.30-2.96)$ & \\
\hline & $\geq 60$ & 666 & $36(5.4)$ & 1 & \\
\hline & Total & 1745 & 168 (9.6) & & \\
\hline & Proteinuria & Total & $\begin{array}{l}\text { With AKI } \\
\mathrm{N}(\%)\end{array}$ & $\begin{array}{l}\text { Stratum-specific adjusted } \\
\text { OR for acute kidney injury }(95 \% \mathrm{Cl})\end{array}$ & $\begin{array}{l}P \text {-value for } \\
\text { interaction }^{\mathrm{b}}\end{array}$ \\
\hline \multirow[t]{3}{*}{ Age 65-79 } & No & 1057 & $57(5.4)$ & 1 & \multirow[t]{3}{*}{0.34} \\
\hline & Yes & 669 & 73 (10.9) & $1.42(0.96-2.08)$ & \\
\hline & Total & 1726 & $130(7.5)$ & & \\
\hline \multirow[t]{3}{*}{ Age 80 or above } & No & 1088 & $89(8.2)$ & 1 & \\
\hline & Yes & 657 & $79(12)$ & $1.11(0.79-1.55)$ & \\
\hline & Total & 1745 & $168(9.6)$ & & \\
\hline
\end{tabular}


The association of two markers of CKD: reducing eGFR and presence of proteinuria were identified as independent risk factors for AKI as previously reported for the general population [47, 48]. We found that age modified the strength of association of reduced eGFR with AKI risk: amongst study participants $<80$ years of age any reduced eGFR was associated with AKI risk, whilst amongst older study participants those with eGFR $<30 \mathrm{ml} / \mathrm{min} /$ $1.73 \mathrm{~m}^{2}$ were especially at risk of AKI. Once eGFR was added to the model, age no longer had a statistically independent association, except through the observed effect modification. There was no evidence of interaction of age with proteinuria as has been described previously for the general population [48]. Other risk factors identified in this study with AKI included male gender, BMI $\geq 30 \mathrm{~kg} / \mathrm{m}^{2}$, hypertension and use of ACEIs \& ARBs, as previously reported for the general population [8, 37, 49], for individuals with diabetes [33] and amongst patients with infections and septic shock [36, 45]. Amongst patients on insulin without oral antiglycaemic medications, it could be hypothesized that patients taking insulin alone were more likely to have Type-I diabetes with a longer disease duration affecting renal-vasculature. However, reliable data on disease duration or type were not available in this dataset and so these aspects of diabetes could not be explored in this study.

This was a population based large cohort study using quality-assured data from the UK general practices spanning a 7-year study period and describes for the first time the factors associated with AKI in this patient population. The use of conceptual framework allowed explanation of possible mediating pathways between risk factors and AKI and independent assessment of the association of both eGFR and history of proteinuria with AKI. The results are potentially generalizable to older patients with diabetes and CAP from other similar-income countries to England with similar demographic profile and access to healthcare.

This study has the limitations from using routinely collected data. Due to the nature of dataset the association of severity of CAP with AKI could not be assessed.

Another potential limitation was missing data; complete data were available for $84.3 \%$ participants and a sensitivity analysis conducted to minimise the effect of missing data using data from $98.8 \%$ of these participants showed no noticeable differences from the primary analyses. Other potential risk factors such as ethnicity, hyperlipidaemia, duration of diabetes and antibiotic use were not measured so the effect-estimates may have residual confounding.
Competing risk of death may have played a role as approximately $30 \%$ of study participants died within 28 days after the CAP diagnosis [50]. Because an eGFR of $<30 \mathrm{ml} / \mathrm{min} / 1.73 \mathrm{~m}^{2}$ is known to be associated with death after admission, the associations seen in this analysis are likely to have been underestimated for the lower eGFR risk group, and could be potentially even higher than we have shown [50]. A competing risk approach would have been particularly appropriate if we had wanted to develop a predictive risk score. However, at this stage we wished simply to understand causality (potential risk factors in this high risk group) [51]. We did not have data on the presentation of CAP the hospital coding variables depend on coding in discharge letters and the clinical presentation is not captured by the diagnostic ICD10 codes in the HES database. We did not use the latest available serum creatinine prior to CAP diagnosis, as we wanted to capture the underlying renal function irrespective of the context of the acute infection, and because test results may not have been available for every patient except for those who were most ill. Most people with diabetes require careful adaptation of diabetes drugs in the context of altered glucose control during infection. These data are observational and the association seen with ACEIs/ARBs may be due to underlying confounding by indication. Those who are prescribed these drugs have typically higher blood pressure, or are more proteinuric, or have heart failure [52]. The standard ACEIs/ARBs prescribed in primary care have a long pharmacological half life [53]; stopping these in the context of infection means that these drugs may stay up to 7 days in the body. Therefore, whilst it is true that people who are on these drugs are at higher risk, it is not clear whether sick-day rules that advise stopping the drugs would indeed prevent AKI in the week following infection. Evaluation of this via a clinical trial would help to elucidate the potential benefits of stopping ACEIs/ ARBs in this setting.

\section{Conclusions}

In summary, amongst older people with diabetes who are diagnosed with CAP, risk of AKI is largely dependent on pre-existing renal function with age modifying this relationship, and prescription of insulin and/or ACE-I/ARB, as well as male sex. The identified risk factors should help primary care and hospital providers identify those patients with CAP who should be monitored more closely (for example, with timely administration of antibiotics and appropriate fluid management) to prevent AKI following pneumonia. 


\section{Appendix}

Table 4 Multivariable analyses of the association between risk factors and acute kidney injury: three Models $(N=3471)$

\begin{tabular}{|c|c|c|c|c|c|c|c|}
\hline Characteristics & & $\begin{array}{l}\text { Model } 1 \\
\text { Adjusted for age, } \\
\text { sex and period } \\
\text { OR }(95 \% \mathrm{Cl})\end{array}$ & $\begin{array}{l}P \text { value }^{\mathrm{a}} \\
\left(\mathrm{P}_{\mathrm{T}}\right)\end{array}$ & $\begin{array}{l}\text { Model } 2 \text { additionally, } \\
\text { adjusted for BMI, smoking, } \\
\text { alcohol-intake } \\
\text { OR }(95 \% \mathrm{Cl})\end{array}$ & $\begin{array}{l}P \text { value } \\
\left(P_{T}\right)\end{array}$ & $\begin{array}{l}\text { Model } 3 \text { additionally } \\
\text { adjusted for hypertension } \\
\text { OR (95\% Cl) }\end{array}$ & $\begin{array}{l}P \text { value } \\
\left(P_{T}\right)\end{array}$ \\
\hline & Females & $0.71(0.56-0.91)$ & 0.007 & $0.69(0.53-0.89)$ & 0.004 & $0.66(0.51-0.86)$ & 0.002 \\
\hline \multirow{5}{*}{$\begin{array}{l}\text { Age categories } \\
\text { years }\end{array}$} & $65-69$ & $0.67(0.44-1.03)$ & 0.11 & $0.59(0.37-0.92)$ & 0.02 & $0.59(0.37-0.92)$ & 0.03 \\
\hline & $70-74$ & $0.62(0.42-0.92)$ & & $0.55(0.36-0.83)$ & & $0.55(0.36-0.83)$ & \\
\hline & $75-79$ & $0.75(0.53-1.06)$ & & $0.68(0.48-0.97)$ & & $0.66(0.46-0.94)$ & \\
\hline & $80-84$ & $0.84(0.61-1.17)$ & & $0.80(0.58-1.12)$ & & $0.78(0.56-1.09)$ & \\
\hline & $\geq 85$ & 1 & & 1 & & 1 & \\
\hline \multirow[t]{5}{*}{ Estimated IMD } & $\begin{array}{l}1 \\
\text { (least deprived) }\end{array}$ & 1 & & Not in model & & Not in model & \\
\hline & 2 & $1.09(0.74-1.60)$ & 0.96 & & & & \\
\hline & 3 & $1.07(0.72-1.59)$ & & & & & \\
\hline & 4 & $1.16(0.78-1.72)$ & & & & & \\
\hline & $\begin{array}{l}5 \\
\text { (most deprived) }\end{array}$ & $1.06(0.69-1.61)$ & & & & & \\
\hline \multirow[t]{3}{*}{ Smoking status } & Non-smoker & 1 & & 1 & & 1 & \\
\hline & Current smoker & $1.12(0.76-1.67)$ & 0.74 & $1.17(0.78-1.74)$ & 0.68 & $1.18(0.79-1.77)$ & 0.65 \\
\hline & Ex-smoker & $1.13(0.83-1.53)$ & & $1.14(0.83-1.55)$ & & $1.14(0.83-1.56)$ & \\
\hline \multirow{4}{*}{$\begin{array}{l}\text { Alcohol intake } \\
\text { (units/day) }\end{array}$} & Non-drinker & 1 & & 1 & & 1 & \\
\hline & Ex-drinker & $0.98(0.64-1.50)$ & 0.27 & $0.97(0.63-1.49)$ & 0.29 & $0.96(0.63-1.48)$ & 0.24 \\
\hline & $\begin{array}{l}\text { Current } \\
\leq 6 \text { units/day }\end{array}$ & $0.83(0.59-1.18)$ & & $0.83(0.58-1.18)$ & & $0.82(0.58-1.17)$ & \\
\hline & $\begin{array}{l}\text { Heavy } \\
>6 \text { units/day }\end{array}$ & $0.52(0.24-1.15)$ & & $0.53(0.24-1.17)$ & & $0.50(0.23-1.11)$ & \\
\hline \multirow[t]{4}{*}{ BMI $\left(\mathrm{kg} / \mathrm{m}^{2}\right)$} & $15-18.4$ & $0.80(0.39-1.64)$ & 0.05 & $0.80(0.39-1.63)$ & 0.06 & $0.80(0.39-1.64)$ & 0.09 \\
\hline & $18.5-24.9$ & 1 & & 1 & & 1 & \\
\hline & $25-29.9$ & $1.00(0.74-1.35)$ & & $1.00(0.74-1.36)$ & & $0.99(0.73-1.34)$ & \\
\hline & $\geq 30$ & $1.44(1.05-1.97)$ & & $1.43(1.04-1.95)$ & & $1.39(1.01-1.90)$ & \\
\hline \multirow{3}{*}{$\begin{array}{l}\text { eGFR } \\
\left(\mathrm{mL} / \mathrm{min} / 1.73 \mathrm{~m}^{2}\right)\end{array}$} & $\leq 29$ & $5.53(3.75-8.15)$ & $<0.0001$ & Not in model & & Not in model & \\
\hline & $30-59$ & $2.74(2.06-3.66)$ & $(<0.0001)$ & & & & \\
\hline & $\geq 60$ & 1 & & & & & \\
\hline Proteinuria & & $1.66(1.30-2.11)$ & $<0.0001$ & Not in model & & Not in model & \\
\hline Hypertension & & $1.63(1.21-2.19)$ & 0.0007 & Not in model & & $1.62(1.21-2.18)$ & 0.0009 \\
\hline $\begin{array}{l}\text { Congestive cardiac } \\
\text { failure }\end{array}$ & & $1.24(0.94-1.64)$ & 0.13 & Not in model & & Not in model & \\
\hline Ischaemic heart disease & & $0.90(0.70-1.15)$ & 0.4 & Not in model & & Not in model & \\
\hline $\begin{array}{l}\text { Cerebrovascular } \\
\text { diseases }\end{array}$ & & $1.00(0.76-1.31)$ & 0.99 & Not in model & & Not in model & \\
\hline Dementia & & $1.05(0.66-1.65)$ & 0.85 & Not in model & & Not in model & \\
\hline Chronic lung disease & & $0.79(0.59-1.06)$ & 0.11 & Not in model & & Not in model & \\
\hline Cancer & & $0.72(0.52-1.01)$ & 0.05 & Not in model & & Not in model & \\
\hline $\begin{array}{l}\text { Connective tissue } \\
\text { disease }\end{array}$ & & $0.63(0.39-1.01)$ & 0.04 & Not in model & & Not in model & \\
\hline Either ACEIs/ ARBs & & $1.96(1.49-2.58)$ & $<0.0001$ & Not in model & & Not in model & \\
\hline
\end{tabular}


Table 4 Multivariable analyses of the association between risk factors and acute kidney injury: three Models ( $N=3471)$ (Continued)

\begin{tabular}{|c|c|c|c|c|c|c|c|}
\hline \multirow[t]{3}{*}{$\mathrm{HbA1C}$} & Good $<7 \%$ & 1 & & \multirow[t]{3}{*}{ Not in model } & & \multirow[t]{3}{*}{ Not in model } & \\
\hline & $\begin{array}{l}\text { Borderline } \\
7-10 \%\end{array}$ & $1.01(0.79-1.30)$ & \multirow[t]{2}{*}{0.98} & & & & \\
\hline & High > 7\% & $0.95(0.52-1.73)$ & & & & & \\
\hline \multirow{4}{*}{$\begin{array}{l}\text { Medication } \\
\text { diabetes }\end{array}$} & None & 1 & & \multirow[t]{4}{*}{ Not in model } & & \multirow[t]{4}{*}{ Not in model } & \\
\hline & Oral & $1.10(0.81-1.50)$ & 0.005 & & & & \\
\hline & Insulin & $2.49(1.46-4.23)$ & & & & & \\
\hline & Both & $1.43(0.99-2.07)$ & & & & & \\
\hline \multirow[t]{2}{*}{ Study period } & $\begin{array}{l}\text { April2004- } \\
\text { September } 2007\end{array}$ & 1 & $<0.0001$ & 1 & $<0.0001$ & 1 & $<0.0001$ \\
\hline & $\begin{array}{l}\text { October2007- } \\
\text { March } 2011\end{array}$ & $2.79(2.07-3.76)$ & $(<0.0001)$ & $2.78(2.06-3.75)$ & $(<0.0001)$ & $2.72(2.01-3.66)$ & $(<0.0001)$ \\
\hline
\end{tabular}

OR odds ratio $\mathrm{Cl}$ confidence interval ${ }^{a}$ likelihood ratio test $\mathrm{P}_{\mathrm{T}} \mathrm{P}$ value for trend IMD index of multiple deprivation ${ }^{\mathrm{b}}$ records with missing individual IMD were substituted by values for general practice $\mathrm{u} / \mathrm{d}$ units/day BMI body mass index eGFR estimated glomerular filtration rate ACEI angiotensin converting enzyme inhibitors ARBs angiotensin II receptor blockers

Table 5 Sensitivity analysis 1: Association of risk factors and acute kidney injury: multivariable analysis excluding smoking status, alcohol intake, body mass index and glycated-haemoglobin levels $(N=4067$, outcome $=344)$

\begin{tabular}{|c|c|c|c|c|c|}
\hline \multicolumn{2}{|l|}{ Characteristics } & \multirow{2}{*}{$\begin{array}{l}\text { Model from primary analysis }{ }^{a} \\
\text { Odds ratio ( } 95 \% \text { confidence interval) } \\
0.64(0.49-0.83)\end{array}$} & \multirow{2}{*}{$\begin{array}{l}P \text { value }^{\mathrm{c}}\left(\mathrm{P}_{\mathrm{T}}\right) \\
0.0008\end{array}$} & \multirow{2}{*}{$\begin{array}{l}\text { Sensitivity analysis } \\
\text { Odds ratio } \\
\text { (95\% confidence interval) } \\
0.64(0.51-0.82)\end{array}$} & \multirow{2}{*}{$\begin{array}{l}\text { value }^{\mathrm{c}}\left(\mathrm{P}_{\mathrm{T}}\right) \\
0.0003\end{array}$} \\
\hline Females & & & & & \\
\hline \multirow[t]{5}{*}{ Age categories (years) } & $65-69$ & $0.83(0.52-1.35)$ & 0.55 & $0.85(0.55-1.31)$ & 0.64 \\
\hline & $70-74$ & $0.70(0.46-1.09)$ & & $0.75(0.51-1.12)$ & \\
\hline & $75-79$ & $0.78(0.54-1.13)$ & & $0.82(0.58-1.15)$ & \\
\hline & $80-84$ & $0.84(0.59-1.18)$ & & $0.93(0.68-1.26)$ & \\
\hline & $\geq 85$ & 1 & & 1 & \\
\hline \multirow[t]{3}{*}{ Smoking status } & Non-smoker & 1 & & Not in model & \\
\hline & Current smoker & $1.39(0.92-2.11)$ & 0.25 & & \\
\hline & Ex-smoker & $1.26(0.91-1.74)$ & & & \\
\hline \multirow[t]{4}{*}{ Alcohol intake (units/day) } & Non-drinker & 1 & & Not in model & \\
\hline & Ex-drinker & $1.00(0.64-1.55)$ & 0.43 & & \\
\hline & Current $\leq 6$ units/day & $0.88(0.61-1.26)$ & & & \\
\hline & Heavy $>6$ units/day & $0.55(0.24-1.26)$ & & & \\
\hline \multirow[t]{4}{*}{ BMI $\left(\mathrm{kg} / \mathrm{m}^{2}\right)$} & $15-18.4$ & $0.95(0.45-2.00)$ & 0.53 & Not in model & \\
\hline & $18.5-24.9$ & 1 & & & \\
\hline & $25-29.9$ & $0.90(0.65-1.23)$ & & & \\
\hline & $\geq 30$ & $1.14(0.82-1.58)$ & & & \\
\hline \multirow[t]{3}{*}{$\mathrm{eGFR}\left(\mathrm{mL} / \mathrm{min} / 1.73 \mathrm{~m}^{2}\right)$} & $\leq 29$ & $4.62(3.06-6.99)$ & $<0.0001$ & $4.43(3.03-6.46)$ & $<0.0001$ \\
\hline & $30-59$ & $2.48(1.84-3.33)$ & $(<0.0001)$ & $2.21(1.68-2.90)$ & $(<0.0001)$ \\
\hline & $\geq 60$ & 1 & & 1 & \\
\hline Proteinuria & & $1.23(0.95-1.59)$ & 0.12 & $1.22(0.96-1.56)$ & 0.10 \\
\hline Hypertension & & $1.27(0.93-1.73)$ & 0.13 & $1.17(0.89-1.55)$ & 0.26 \\
\hline Congestive cardiac failure & & $1.03(0.76-1.39)$ & 0.86 & $0.97(0.73-1.29)$ & 0.83 \\
\hline Ischaemic heart disease & & $0.76(0.58-1.00)$ & 0.04 & $0.77(0.60-0.98)$ & 0.03 \\
\hline Cerebrovascular diseases & & $0.90(0.68-1.20)$ & 0.47 & $0.96(0.74-1.24)$ & 0.74 \\
\hline Dementia & & $1.17(0.73-1.88)$ & 0.53 & $1.10(0.73-1.67)$ & 0.65 \\
\hline
\end{tabular}


Table 5 Sensitivity analysis 1: Association of risk factors and acute kidney injury: multivariable analysis excluding smoking status, alcohol intake, body mass index and glycated-haemoglobin levels $(N=4067$, outcome $=344)$ (Continued)

\begin{tabular}{|c|c|c|c|c|c|}
\hline \multicolumn{2}{|l|}{ Chronic lung disease } & $0.79(0.58-1.07)$ & 0.12 & $0.90(0.68-1.18)$ & 0.43 \\
\hline \multicolumn{2}{|l|}{ Cancer } & $0.76(0.54-1.07)$ & 0.11 & $0.73(0.53-1.01)$ & 0.05 \\
\hline \multicolumn{2}{|c|}{ Connective tissue diseases } & $0.66(0.40-1.08)$ & 0.08 & $0.68(0.43-1.07)$ & 0.08 \\
\hline \multicolumn{2}{|l|}{ Either ACEI/ARBs } & $1.59(1.19-2.13)$ & 0.002 & $1.66(1.27-2.17)$ & 0.0001 \\
\hline \multirow[t]{3}{*}{ HBA1C levels } & Good $<7 \%$ & 1 & & Not in model & \\
\hline & Borderline 7-10\% & $0.82(0.62-1.09)$ & 0.38 & & \\
\hline & High >7\% & $0.82(0.43-1.54)$ & & & \\
\hline \multirow[t]{4}{*}{ Medication diabetes } & None & 1 & & 1 & \\
\hline & Oral & $1.05(0.75-1.46)$ & 0.05 & $1.00(0.74-1.33)$ & 0.08 \\
\hline & Insulin & $2.27(1.27-4.05)$ & & $1.89(1.14-3.11)$ & \\
\hline & Both & $1.11(0.72-1.71)$ & & $1.03(0.72-1.47)$ & \\
\hline \multirow[t]{2}{*}{ Study period } & April 2004-September 2007 & 1 & $<0.0001$ & 1 & $<0.0001$ \\
\hline & October 2007-March 2011 & $2.90(2.14-3.95)$ & $(<0.0001)$ & $2.94(2.22-3.89)$ & $(<0.0001)$ \\
\hline
\end{tabular}

Table 6 Sensitivity analysis 2: Risk factors associated with acute kidney injury multivariable model with ICD10-N17 or N19 code for outcome ( $N=3471$ outcome $=373$ )

\begin{tabular}{|c|c|c|c|c|c|}
\hline Characteristics & & $\begin{array}{l}\text { Model from primary analysis } \\
\text { OR }(95 \% \text { Cl })\end{array}$ & $P$ value $^{\mathrm{b}}\left(\mathrm{P}_{\mathrm{T}}\right)$ & $\begin{array}{l}\text { Sensitivity analysis } \\
\text { Odds Ratio }^{\mathrm{a}} \\
\text { (95\% confidence interval) }\end{array}$ & $P$ value $^{\mathrm{b}}\left(\mathrm{P}_{\mathrm{T}}\right)$ \\
\hline Females & & $0.64(0.49-0.83)$ & 0.0008 & $0.63(0.49-0.80)$ & 0.0002 \\
\hline \multirow[t]{5}{*}{ Age categories years } & $65-69$ & $0.83(0.52-1.35)$ & 0.55 & $1.00(0.65-1.54)$ & 0.52 \\
\hline & $70-74$ & $0.70(0.46-1.09)$ & & $0.75(0.50-1.11)$ & \\
\hline & $75-79$ & $0.78(0.54-1.13)$ & & $0.82(0.58-1.15)$ & \\
\hline & $80-84$ & $0.84(0.59-1.18)$ & & $0.90(0.66-1.23)$ & \\
\hline & $\geq 85$ & 1 & & 1 & \\
\hline \multirow[t]{3}{*}{ Smoking status } & Non-smoker & 1 & 0.25 & 1 & 0.32 \\
\hline & Current smoker & $1.39(0.92-2.11)$ & & $1.32(0.91-1.92)$ & \\
\hline & Ex-smoker & $1.26(0.91-1.74)$ & & $1.19(0.89-1.59)$ & \\
\hline \multirow[t]{4}{*}{ Alcohol intake (units/day) } & Non-drinker & 1 & 0.43 & 1 & 0.18 \\
\hline & Ex-drinker & $1.00(0.64-1.55)$ & & $1.17(0.78-1.76)$ & \\
\hline & Current $\leq 6$ units/day & $0.88(0.61-1.26)$ & & $0.99(0.71-1.39)$ & \\
\hline & Heavy $>6$ units/day & $0.55(0.24-1.26)$ & & $0.54(0.25-1.16)$ & \\
\hline \multirow[t]{4}{*}{ BMI $\left(\mathrm{kg} / \mathrm{m}^{2}\right)$} & $15-18.4$ & $0.95(0.45-2.00)$ & 0.53 & $0.80(0.40-1.61)$ & 0.28 \\
\hline & $18.5-24.9$ & 1 & & 1 & \\
\hline & $25-29.9$ & $0.90(0.65-1.23)$ & & $0.84(0.63-1.11)$ & \\
\hline & $\geq 30$ & $1.14(0.82-1.58)$ & & $1.10(0.81-1.47)$ & \\
\hline \multirow[t]{3}{*}{ eGFR (mL/min/1.73m²) } & $\leq 29$ & $4.62(3.06-6.99)$ & $<0.0001$ & $4.86(3.34-7.09)$ & $<0.0001$ \\
\hline & $30-59$ & $2.48(1.84-3.33)$ & $(<0.0001)$ & $2.47(1.89-3.23)$ & $(<0.0001)$ \\
\hline & $\geq 60$ & 1 & & 1 & \\
\hline Proteinuria & & $1.23(0.95-1.59)$ & 0.12 & $1.22(0.96-1.54)$ & 0.10 \\
\hline Hypertension & & $1.27(0.93-1.73)$ & 0.13 & $1.19(0.90-1.57)$ & 0.21 \\
\hline Congestive cardiac failure & & $1.03(0.76-1.39)$ & 0.86 & $1.05(0.80-1.39)$ & 0.71 \\
\hline
\end{tabular}


Table 6 Sensitivity analysis 2: Risk factors associated with acute kidney injury multivariable model with ICD10-N17 or N19 code for outcome $(N=3471$ outcome $=373)$ (Continued)

\begin{tabular}{|c|c|c|c|c|c|}
\hline \multicolumn{2}{|l|}{ Ischaemic heart disease } & $0.76(0.58-1.00)$ & 0.04 & $0.77(0.60-0.98)$ & 0.03 \\
\hline \multicolumn{2}{|l|}{ Cerebrovascular disease } & $0.90(0.68-1.20)$ & 0.47 & $0.81(0.62-1.05)$ & 0.10 \\
\hline \multicolumn{2}{|l|}{ Dementia } & $1.17(0.73-1.88)$ & 0.53 & $1.17(0.76-1.82)$ & 0.48 \\
\hline \multicolumn{2}{|l|}{ Chronic lung disease } & $0.79(0.58-1.07)$ & 0.12 & $0.75(0.57-0.98)$ & 0.03 \\
\hline \multicolumn{2}{|l|}{ Cancer } & $0.76(0.54-1.07)$ & 0.11 & $0.89(0.66-1.19)$ & 0.42 \\
\hline \multicolumn{2}{|l|}{ Connective tissue diseases } & $0.66(0.40-1.08)$ & 0.08 & $0.73(0.47-1.12)$ & 0.14 \\
\hline \multicolumn{2}{|l|}{ Either ACEI/ ARBs } & $1.59(1.19-2.13)$ & 0.002 & $1.48(1.14-1.92)$ & 0.003 \\
\hline \multirow[t]{3}{*}{ Glycated haemoglobin levels } & Good $<7 \%$ & 1 & & 1 & \\
\hline & Borderline $7-10 \%$ & $0.82(0.62-1.09)$ & 0.38 & $0.85(0.66-1.10)$ & 0.42 \\
\hline & High $>7 \%$ & $0.82(0.43-1.54)$ & & $1.03(0.60-1.77)$ & \\
\hline \multirow[t]{4}{*}{ Medication-diabetes } & None & 1 & & 1 & \\
\hline & Oral & $1.05(0.75-1.46)$ & 0.05 & $1.02(0.75-1.38)$ & 0.02 \\
\hline & Insulin & $2.27(1.27-4.05)$ & & $2.27(1.34-3.84)$ & \\
\hline & Both & $1.11(0.72-1.71)$ & & $1.10(0.74-1.62)$ & \\
\hline \multirow[t]{2}{*}{ Study period } & April 2004-September 2007 & 1 & $<0.0001$ & 1 & $<0.0001$ \\
\hline & October 2007-March 2011 & $2.90(2.14-3.95)$ & $(<0.0001)$ & $2.38(1.83-3.10)$ & $(<0.0001)$ \\
\hline
\end{tabular}

adjusted for all variables in table BMI body mass index eGFR estimated glomerular filtration rate ACEI angiotensin converting enzyme inhibitors ARBs angiotensin II receptor blockers ${ }^{\mathrm{b}}$ likelihood ratio test $\mathrm{P}_{\mathrm{T}} P$ value for trend

Table 7 Sensitivity analysis 3: Risk factors associated with acute kidney injury multivariable model restricted to hospitalised patients $(N=3047$ outcome $=298)$

\begin{tabular}{|c|c|c|c|c|c|}
\hline Characteristics & & $\begin{array}{l}\text { Primary analysis } \\
\text { OR }(95 \% \mathrm{Cl})^{\mathrm{b}}\end{array}$ & $P$ value $^{\mathrm{a}}\left(\mathrm{P}_{\mathrm{T}}\right)$ & $\begin{array}{l}\text { Sensitivity analysis } \\
\text { OR }(95 \% \mathrm{Cl})^{\mathrm{b}}\end{array}$ & $P$ value ${ }^{a}(\mathrm{PT})$ \\
\hline Gender & Female & $0.64(0.49-0.83)$ & 0.0008 & $0.64(0.49-0.84)$ & 0.001 \\
\hline \multirow[t]{5}{*}{ Age categories years } & $65-69$ & $0.83(0.52-1.35)$ & 0.55 & $0.84(0.52-1.37)$ & 0.49 \\
\hline & $70-74$ & $0.70(0.46-1.09)$ & & $0.70(0.45-1.09)$ & \\
\hline & $75-79$ & $0.78(0.54-1.13)$ & & $0.75(0.52-1.10)$ & \\
\hline & $80-84$ & $0.84(0.59-1.18)$ & & $0.82(0.58-1.16)$ & \\
\hline & $\geq 85$ & 1 & & 1 & \\
\hline \multirow[t]{3}{*}{ Smoking status } & Non-smoker & 1 & 0.25 & 1 & 0.32 \\
\hline & Current smoker & $1.39(0.92-2.11)$ & & $1.34(0.88-2.04)$ & \\
\hline & Ex-smoker & $1.26(0.91-1.74)$ & & $1.25(0.90-1.73)$ & \\
\hline \multirow[t]{4}{*}{ Alcohol intake (units/day) } & Non-drinker & 1 & 0.43 & 1 & 0.59 \\
\hline & Ex-drinker & $1.00(0.64-1.55)$ & & $1.00(0.64-1.56)$ & \\
\hline & Current $\leq 6$ units/day & $0.88(0.61-1.26)$ & & $0.88(0.61-1.28)$ & \\
\hline & Heavy $>6$ units/day & $0.55(0.24-1.26)$ & & $0.61(0.27-1.40)$ & \\
\hline \multirow[t]{4}{*}{ BMI $\left(\mathrm{kg} / \mathrm{m}^{2}\right)$} & $15-18.4$ & $0.95(0.45-2.00)$ & 0.53 & $1.00(0.47-2.13)$ & 0.56 \\
\hline & $18.5-24.9$ & 1 & & 1 & \\
\hline & $25-29.9$ & $0.90(0.65-1.23)$ & & $0.89(0.65-1.22)$ & \\
\hline & $\geq 30$ & $1.14(0.82-1.58)$ & & $1.12(0.80-1.56)$ & \\
\hline \multirow[t]{3}{*}{$\mathrm{eGFR}\left(\mathrm{mL} / \mathrm{min} / 1.73 \mathrm{~m}^{2}\right)$} & $\leq 29$ & $4.62(3.06-6.99)$ & $<0.0001$ & $4.54(2.98-6.90)$ & $<0.0001$ \\
\hline & $30-59$ & $2.48(1.84-3.33)$ & $(<0.0001)$ & $2.40(1.78-3.25)$ & $(<0.0001)$ \\
\hline & $\geq 60$ & 1 & & 1 & \\
\hline Proteinuria & & $1.23(0.95-1.59)$ & 0.12 & $1.19(0.92-1.55)$ & 0.19 \\
\hline Hypertension & & $1.27(0.93-1.73)$ & 0.13 & $1.30(0.95-1.78)$ & 0.09 \\
\hline
\end{tabular}


Table 7 Sensitivity analysis 3: Risk factors associated with acute kidney injury multivariable model restricted to hospitalised patients ( $N=3047$ outcome $=298)$ (Continued)

\begin{tabular}{|c|c|c|c|c|c|}
\hline \multicolumn{2}{|l|}{ Congestive cardiac failure } & $1.03(0.76-1.39)$ & 0.86 & $1.06(0.78-1.43)$ & 0.73 \\
\hline \multicolumn{2}{|l|}{ Ischaemic heart disease } & $0.76(0.58-1.00)$ & 0.04 & $0.75(0.57-0.98)$ & 0.03 \\
\hline \multicolumn{2}{|l|}{ Cerebrovascular disease } & $0.90(0.68-1.20)$ & 0.47 & $0.89(0.67-1.19)$ & 0.44 \\
\hline \multicolumn{2}{|l|}{ Dementia } & $1.17(0.73-1.88)$ & 0.53 & $1.26(0.78-2.04)$ & 0.36 \\
\hline \multicolumn{2}{|l|}{ Chronic lung disease } & $0.79(0.58-1.07)$ & 0.12 & $0.76(0.56-1.03)$ & 0.08 \\
\hline \multicolumn{2}{|l|}{ Cancer } & $0.76(0.54-1.07)$ & 0.11 & $0.77(0.55-1.09)$ & 0.13 \\
\hline \multicolumn{2}{|l|}{ Connective tissue diseases } & $0.66(0.40-1.08)$ & 0.08 & $0.64(0.39-1.05)$ & 0.07 \\
\hline \multicolumn{2}{|l|}{ Either ACEI/ ARBs } & $1.59(1.19-2.13)$ & 0.002 & $1.57(1.17-2.11)$ & 0.002 \\
\hline \multirow[t]{3}{*}{ Glycated haemoglobin levels } & Good $<7 \%$ & 1 & & 1 & \\
\hline & Borderline $7-10 \%$ & $0.82(0.62-1.09)$ & 0.38 & $0.83(0.62-1.10)$ & 0.40 \\
\hline & High > 7\% & $0.82(0.43-1.54)$ & & $0.82(0.43-1.56)$ & \\
\hline \multirow[t]{4}{*}{ Medication-diabetes } & None & 1 & 0.05 & 1 & 0.03 \\
\hline & Oral & $1.05(0.75-1.46)$ & & $1.05(0.75-1.48)$ & \\
\hline & Insulin & $2.27(1.27-4.05)$ & & $2.43(1.34-4.40)$ & \\
\hline & Both & $1.11(0.72-1.71)$ & & $1.11(0.72-1.71)$ & \\
\hline \multirow[t]{3}{*}{ Study period } & April 2004-September 2007 & 1 & $<0.0001$ & 1 & $<0.0001$ \\
\hline & & & $(<0.0001)$ & & \\
\hline & October 2007-March 2011 & $2.90(2.14-3.95)$ & $(<0.0001)$ & $2.74(2.01-3.73)$ & $(<0.0001)$ \\
\hline
\end{tabular}

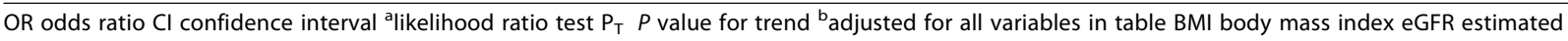
glomerular filtration rate ACEI angiotensin converting enzyme inhibitors ARBs angiotensin II receptor blockers Sep. September Oct. October

\section{Abbreviations}

ACEl: Angiotensin converting enzyme inhibitor; AKl: Acute kidney injury; AKIN: Acute Kidney Injury Network; aOR: Adjusted odds ratio;

ARB: Angiotensin II receptor blocker; BMI: Body mass index;

CAP: Community-acquired pneumonia; Cl: Confidence interval; CKD: Chronic kidney disease; CPRD: Clinical Practice Research Datalink; eGFR: Estimated glomerular filtration rate; HbA1C: Glycated-haemoglobin; HES: Hospital Episode Statistics; ICD: International Classification of Diseases; IMD: Index of Multiple Deprivation; KDIGO: Kidney Disease: Improving Global outcomes; OR: Odds ratio

\section{Acknowledgements}

None.

\section{Funding}

This work was supported by the National Institute for Health Research [CDF 2010-03-32 to S.L.T.] and Kidney Research UK [ST2/2011 to H.I.M.]. LT is funded by a Wellcome Trust Intermediate Clinical Fellowship (101,143/Z/13/Z).

The funders of the study had no role in study design, data collection and analysis, decision to publish, or preparation of the manuscript. The views expressed in this publication are those of the authors and not necessarily those of the UK National Health Service, the National Institute for Health Research, the Department of Health nor Kidney Research UK.

\section{Availability of data and materials}

The data that support the findings of this study were used under licence and belong to the Clinical Practice Research Datalink, and so are not publicly available. We will therefore ultimately be governed in respect of data sharing by the data owners: any requests to share will be subject to their permission, and to the approval of the ethics committees overseeing the use of these data sources.

\section{Authors' contributions}

AJ planned and conducted the analysis, interpretation of data and drafted the manuscript. HIM supported the data extraction and cleaning. SLT, DN, LT and HIM made substantial contribution to study design. All authors contributed to and approved the final manuscript.
Competing interests

The authors declare that they have no competing interests.

\section{Consent for publication}

Not applicable.

\section{Ethics approval and consent to participate}

This study was approved by the Independent Scientific Advisory Group of MHRA (ISAC reference 11_033AMn) and the London School of Hygiene and Tropical Medicine Ethics Committee (LSHTM reference 6116).

\section{Publisher's Note}

Springer Nature remains neutral with regard to jurisdictional claims in published maps and institutional affiliations.

Received: 17 November 2016 Accepted: 22 April 2017

Published online: 01 May 2017

\section{References}

1. Kidney Disease: Improving global outcomes (KDIGO) acute kidney injury working group. KDIGO clinical practice guideline for acute kidney injury. Kidney Int Suppl (2012). 2012;2(1):1-138. doi:10.1038/kisup.2012.3.

2. Mehta RL, Bouchard J, Soroko SB, Ikizler TA, Paganini EP, Chertow GM, et al. Sepsis as a cause and consequence of acute kidney injury: program to improve Care in Acute Renal Disease. Intensive Care Med. 2011;37(2):241-8. doi:10.1007/s00134-010-2089-9.

3. Susantitaphong P, Cruz DN, Cerda J, Abulfaraj M, Alqahtani F, Koulouridis I, et al. World incidence of AKI: a meta-analysis. Clin J Am Soc Nephrol. 2013; 8(9):1482-93. doi:10.2215/CJN.00710113.

4. Coca SG, Cho KC, Hsu CY. Acute kidney injury in the elderly: predisposition to chronic kidney disease and vice versa. Nephron Clin Pract. 2011; 119(Suppl 1):c19-24. doi:10.1159/000328023.

5. Ishani A, Xue JL, Himmelfarb J, Eggers PW, Kimmel PL, Molitoris BA, et al. Acute kidney injury increases risk of ESRD among elderly. J Am Soc Nephrol. 2009;20(1):223-8. doi:10.1681/ASN.2007080837. 
6. Schmitt R, Coca S, Kanbay M, Tinetti ME, Cantley LG, Parikh CR. Recovery of kidney function after acute kidney injury in the elderly: a systematic review and meta-analysis. Am J Kidney Dis. 2008;52(2):262-71. doi:10.1053/j.ajkd. 2008.03.005.

7. Ali T, Khan I, Simpson W, Prescott G, Townend J, Smith W, et al. Incidence and outcomes in acute kidney injury: a comprehensive population-based study. J Am Soc Nephrol. 2007;18(4):1292-8. doi:10.1681/ASN.2006070756.

8. Leblanc M, Kellum JA, Gibney RT, Lieberthal W, Tumlin J, Mehta R. Risk factors for acute renal failure: inherent and modifiable risks. Curr Opin Crit Care. 2005:11(6):533-6.

9. Shah BR, Hux JE. Quantifying the risk of infectious diseases for people with diabetes. Diabetes Care. 2003;26(2):510-3.

10. Ljubic S, Balachandran A, Pavlic-Renar I, Barada A, Metelko Z. Pulmonary infections in diabetes mellitus. Diabetol Croat. 2005;33(4):115-24.

11. Ruben FL, Dearwater SR, Norden CW, Kuller LH, Gartner K, Shalley A, et al. Clinical infections in the noninstitutionalized geriatric age group: methods utilized and incidence of infections. The Pittsburgh Good health study. Am J Epidemiol. 1995;141(2):145-57.

12. Koivula I, Sten M, Makela PH. Risk factors for pneumonia in the elderly. Am J Med. 1994;96(4):313-20.

13. Jackson ML, Neuzil KM, Thompson WW, Shay DK, Yu O, Hanson CA, et al. The burden of community-acquired pneumonia in seniors: results of a populationbased study. Clin Infect Dis. 2004;39(11):1642-50. doi:10.1086/425615.

14. Kornum JB, Thomsen RW, Riis A, Lervang HH, Schonheyder HC, Sorensen HT. Diabetes, glycemic control, and risk of hospitalization with pneumonia: a population-based case-control study. Diabetes Care. 2008;31(8):1541-5. doi:10.2337/dc08-0138.

15. Torres A, Blasi F, Dartois N, Akova M. Which individuals are at increased risk of pneumococcal disease and why? Impact of COPD, asthma, smoking, diabetes, and/or chronic heart disease on community-acquired pneumonia and invasive pneumococcal disease. Thorax. 2015;70(10):984-9. doi:10.1136/ thoraxinl-2015-206780.

16. Bagshaw SM, Lapinsky S, Dial S, Arabi Y, Dodek P, Wood G, et al. Acute kidney injury in septic shock: clinical outcomes and impact of duration of hypotension prior to initiation of antimicrobial therapy. Intensive Care Med. 2009:35(5):871-81. doi:10.1007/s00134-008-1367-2.

17. Bagshaw SM, Uchino S, Bellomo R, Morimatsu H, Morgera S, Schetz M, et al. Septic acute kidney injury in critically ill patients: clinical characteristics and outcomes. Clin J Am Soc Nephrol. 2007;2(3):431-9. doi:10.2215/CJN.03681106.

18. Neveu $H$, Kleinknecht $D$, Brivet $F$, Loirat $P$, Landais $P$. Prognostic factors in acute renal failure due to sepsis. Results of a prospective multicentre study. The French study group on acute renal failure. Nephrol Dial Transplant. 1996;11(2):293-9.

19. Murugan R, Karajala-Subramanyam V, Lee M, Yende S, Kong L, Carter M, et al. Acute kidney injury in non-severe pneumonia is associated with an increased immune response and lower survival. Kidney Int. 2010; 77(6):527-35. doi:10.1038/ki.2009.502

20. Yende $S$, van der Poll T, Lee M, Huang DT, Newman AB, Kong L, et al. The influence of pre-existing diabetes mellitus on the host immune response and outcome of pneumonia: analysis of two multicentre cohort studies. Thorax. 2010;65(10):870-7. doi:10.1136/thx.2010.136317.

21. Breidthardt T, Christ-Crain M, Stolz D, Bingisser R, Drexler B, Klima T, et al. A combined cardiorenal assessment for the prediction of acute kidney injury in lower respiratory tract infections. Am J Med. 2012;125(2):168-75.

22. Chiu PF, Huang $\mathrm{CH}$, Liou HH, Wu CL, Wang SC, Chang CC. Long-term renal outcomes of episodic urinary tract infection in diabetic patients. J Diabetes Complicat. 2013;27(1):41-3. doi:10.1016/j.jdiacomp.2012.08.005.

23. Akram AR, Singanayagam A, Choudhury G, Mandal P, Chalmers JD, Hill AT. Incidence and prognostic implications of acute kidney injury on admission in patients with community-acquired pneumonia. Chest. 2010;138(4):82532. doi:10.1378/chest.09-3071

24. Musso CG, Liakopoulos V, loannidis I, Eleftheriadis T, Stefanidis I. Acute renal failure in the elderly: particular characteristics. Int Urol Nephrol. 2006;38(3-4) 787-93. doi:10.1007/s11255-006-0084-4

25. CPRD. The Clinical Practice Research Datalink. 2014. http://www.cprd.com/ intro.asp. Accessed 28 Aug 2014.

26. Herrett E, Gallagher AM, Bhaskaran K, Forbes H, Mathur R, van Staa T, et al. Data resource profile: clinical practice Research Datalink (CPRD). Int J Epidemiol. 2015; doi:10.1093/ije/dyv098.

27. Health and Social Care Information Centre. Hospital Episode Statistics. 2014 http://www.hscic.gov.uk/hes. Accessed 28 Aug 2014.
28. McDonald HI, Nitsch D, Millett ER, Sinclair A, Thomas SL. New estimates of the burden of acute community-acquired infections among older people with diabetes mellitus: a retrospective cohort study using linked electronic health records. Diabet Med. 2013; doi:10.1111/dme.12384.

29. Millett ER, Quint JK, Smeeth L, Daniel RM, Thomas SL. Incidence of community-acquired lower respiratory tract infections and pneumonia among older adults in the United Kingdom: a population-based study. PLoS One. 2013;8(9):e75131. doi:10.1371/journal.pone.0075131.

30. The Information Centre. Online GP practice results database. Quality and Outcomes Framework 2005/06 for GP practices 2006. http://www.qof.ic.nhs. uk/0506/. Accessed 18 Aug 2014.

31. Bellomo R, Ronco C, Kellum JA, Mehta RL, Palevsky P. Acute dialysis quality initiative W. Acute renal failure - definition, outcome measures, animal models, fluid therapy and information technology needs: the second International consensus conference of the acute dialysis quality initiative (ADQI) group. Crit Care. 2004;8(4):R204-12. doi:10.1186/cc2872.

32. Lewis JD, Bilker WB, Weinstein RB, Strom BL. The relationship between time since registration and measured incidence rates in the general practice Research database. Pharmacoepidemiol Drug Saf. 2005;14(7):443-51. doi:10. 1002/pds.1115.

33. Girman CJ, Kou TD, Brodovicz K, Alexander CM, O'Neill EA, Engel S, et al. Risk of acute renal failure in patients with type 2 diabetes mellitus. Diabet Med. 2012;29(5):614-21. doi:10.1111/j.1464-5491.2011.03498.x.

34. Mittalhenkle A, Stehman-Breen CO, Shlipak MG, Fried LF, Katz R, Young BA, et al. Cardiovascular risk factors and incident acute renal failure in older adults: the cardiovascular health study. Clin J Am Soc Nephrol. 2008;3(2): 450-6. doi:10.2215/CJN.02610607.

35. National Institute for Health and Care Excellence. Acute kidney injury: prevention, detection and management of acute kidney injury up to the point of renal replacement therapy. (Clinical guideline 169)2013.

36. Plataki M, Kashani K, Cabello-Garza J, Maldonado F, Kashyap R, Kor DJ, et al. Predictors of acute kidney injury in septic shock patients: an observational cohort study. Clin J Am Soc Nephrol. 2011;6(7):1744-51. doi:10.2215/CJN. 05480610.

37. Rewa O, Bagshaw SM. Acute kidney injury-epidemiology, outcomes and economics. Nat Rev Nephrol. 2014;10(4):193-207. doi:10.1038/nrneph.2013.282.

38. Office of National Statistics. 2011 Rural-Urban Classification for small area geographies. 2011. http://www.ons.gov.uk/ons/guide-method/ geography/products/area-classifications/2011-rural-urban/index.html. Accessed 02 Feb 2014

39. McDonald HI, Thomas SL, Millett ER, Nitsch D. CKD and the risk of acute, community-acquired infections among older people with diabetes mellitus: a retrospective cohort study using electronic health records. Am J Kidney Dis. 2015;66(1):60-8. doi:10.1053/j.ajkd.2014.11.027.

40. Levey AS, Stevens LA, Schmid CH, Zhang YL, Castro AF 3rd, Feldman HI, et al. A new equation to estimate glomerular filtration rate. Ann Intern Med. 2009:150(9):604-12.

41. Mehta RL, Kellum JA, Shah SV, Molitoris BA, Ronco C, Warnock DG, et al. Acute kidney injury Network: report of an initiative to improve outcomes in acute kidney injury. Crit Care. 2007;11(2):R31. doi:10.1186/cc5713.

42. Victora CG, Huttly SR, Fuchs SC, Olinto MT. The role of conceptual frameworks in epidemiological analysis: a hierarchical approach. Int J Epidemiol. 1997;26(1):224-7.

43. Peduzzi $P$, Concato J, Kemper E, Holford TR, Feinstein AR. A simulation study of the number of events per variable in logistic regression analysis. J Clin Epidemiol. 1996;49(12):1373-9.

44. Tomlinson LA, Riding AM, Payne RA, Abel GA, Tomson CR, Wilkinson IB. The accuracy of diagnostic coding for acute kidney injury in England - a single centre study. BMC Nephrol. 2013;14 doi:10.1186/1471-2369-14-58.

45. Iwagami M, Mansfield K, Quint J, Nitsch D, Tomlinson L. Diagnosis of acute kidney injury and its association with in-hospital mortality in patients with infective exacerbations of bronchiectasis: cohort study from a UK nationwide database. BMC Pulm Med. 2016;16(1):1-8. doi:10. 1186/s12890-016-0177-5.

46. Kolhe NV, Muirhead AW, Wilkes SR, Fluck RJ, Taal MW. The epidemiology of hospitalised acute kidney injury not requiring dialysis in England from 1998 to 2013: retrospective analysis of hospital episode statistics. Int J Clin Pract. 2016;70(4):330-9. doi:10.1111/ijcp.12774.

47. Hsu C, Ordonez J, Chertow G, Fan D, McCulloch C, Go A. The risk of acute renal failure in patients with chronic kidney disease. Kidney Int. 2008;74(1):101-7. 
48. Grams ME, Astor BC, Bash LD, Matsushita K, Wang Y, Coresh J. Albuminuria and estimated glomerular filtration rate independently associate with acute kidney injury. J Am Soc Nephrol. 2010;21(10):1757-64. doi:10.1681/ASN. 2010010128.

49. Kidney Disease: Improving Global Outcomes (KDIGO) Acute Kidney Injury Working Group. KDIGO Clinical Practice Guideline for Acute Kidney Injury. Online Appendices A-F. 2012. http://www.kdigo.org/clinical_practice_ guidelines/pdf/KDIGO-AKI-Suppl-Appendices-A-F_March2012.pdf. Accessed 04 Sept 2014

50. McDonald HI, Nitsch D, Millett ER, Sinclair A, Thomas SL. Are pre-existing markers of chronic kidney disease associated with short-term mortality following acute community-acquired pneumonia and sepsis? A cohort study among older people with diabetes using electronic health records. Nephrol Dial Transplant. 2015;30(6):1002-9. doi:10.1093/ndt/gfu401.

51. Noordzii M, Leffondré K, van Stralen KJ, Zoccali C, Dekker FW, Jager KJ. When do we need competing risks methods for survival analysis in nephrology? Nephrol Dial Transplant. 2013;28(11):2670-7.

52. Mansfield KE, Nitsch D, Smeeth L, Bhaskaran K, Tomlinson LA. Prescription of renin-angiotensin system blockers and risk of acute kidney injury: a population-based cohort study. BMJ Open. 2016;6(12). doi:10.1136/ bmjopen-2016-012690.

53. British National Formulary. Drugs affecting the renin-angiotensin system 2017. https://www.evidence.nhs.uk/formulary/bnf/current/2-cardiovascularsystem/25-hypertension-and-heart-failure/255-drugs-affecting-the-reninangiotensin-system. Accessed 26 Feb 2017.

\section{Submit your next manuscript to BioMed Central and we will help you at every step:}

- We accept pre-submission inquiries

- Our selector tool helps you to find the most relevant journal

- We provide round the clock customer support

- Convenient online submission

- Thorough peer review

- Inclusion in PubMed and all major indexing services

- Maximum visibility for your research

Submit your manuscript at www.biomedcentral.com/submit 